\title{
Preface to the First Edition
}

Growing up in San Francisco during the 1960s, I learned early in life about the power of racism. Home was defined by segregation: my parents, like other immigrants from the Philippines, could not rent an apartment in most parts of the city, where the common response was "no Orientals allowed." My father, who first came to this country in the late 1920s, had already faced decades of segregation and knew the limits that it imposed. A United States Navy veteran who had been denied a law enforcement career because of discrimination, he worked as a clerk for the post office, where civil service rules protected workers of color. A former elementary school teacher with two college degrees, my mother also understood the barriers imposed by race and nationality, and she thought it best to abandon her career. She worked as a waitress and later joined my father in the safety of government employment.

Living in a working-class neighborhood and attending a Catholic school, I encountered a steady stream of racial slurs- "chink," "chinaman," "jap," "nip"-from my earliest days in school and in the local parks and playgrounds. The name-calling was never fully accurate-there didn't seem to be enough Filipinos around at the time to require a special epithet—but it was no less assaultive. Raised at a time when the Asian American population was much smaller than it is today, I tried hard to fit in. This meant trying especially hard to be an "American," even though I had never lived anywhere outside of California. My name was too foreign sounding, and it could be a source of shame. I felt compelled to hide the experiences that I gained through encounters with relatives; language and cultural traditions seemed too different from the norm, and could only lead to derision or exclusion.

Fortunately, the overt discrimination began to decline as I grew older. Yet racism often appeared in different and more subtle forms. I recall, for example, 
going on school trips to visit Chinatown and Japantown and observing my classmates' surprise that I could understand neither Chinese nor Japanese. Over time I also witnessed changes in the population-more people who looked like me began moving into the neighborhood-and in public attitudes about race. I felt less pressure to conform, and I gave up trying to prove that I was more American than anyone else. My sense of racial and ethnic identity became more concrete, and the fears of nonconformity receded. Still, the memories of childhood are deeply etched in my mind, and they remain as clear today as they did thirty years ago.

I have engaged in this exercise in autobiography because anyone writing a book about discrimination and civil rights should be clear about their perspectives on race. My outlook on race was shaped early in life, and race continues to pervade my social reality. Thus, I make no pretense about being neutral or objective about racism. As both a child and an adult I have been subjected to racial discrimination, and as a civil rights lawyer I have spent most of my professional life trying to fight it. This book is as much a reflection of my personal experiences as it is an analysis of contemporary race relations.

In this book I examine racial discrimination through multiple lenses. First, I focus on the experiences of discrimination against the members of one racial group-Asian Americans-within the broader landscape of urban race relations. Second, I focus on the legal system's response to racial discrimination, in particular the doctrines and policies embedded in constitutional law and civil rights legislation. The intersection of these inquiries-how civil rights laws affect Asian Americans and in turn are affected by Asian Americansis the central theme of this book.

It would be impossible to cover the full array of civil rights issues affecting Asian Americans in the span of a few chapters. I make no attempt to do so. A useful overview is provided by a report produced by the United States Commission on Civil Rights entitled Civil Rights Issues Facing Asian Americans in the 1990s. The report includes extensive discussions of the many court cases affecting Asian Americans, and it analyzes several areas, such as employment discrimination, police-community relations, and higher-education admissions, that receive only limited treatment in this book.

My selection of topics has been influenced by my personal work in the area of civil rights. Having been active in Asian American issues in both Northern and Southern California since the late 1970s, I have been a participant in many of the cases and controversies highlighted in this book. Several examples are drawn from areas of law and public policy on which I have worked in the past: litigation involving anti-Asian violence, language rights, 
and voting rights; advocacy on immigrants' rights; efforts to improve interethnic relations in Los Angeles after the 1992 riots; and the defense of affirmative action in the wake of California's Proposition 209. Although I continue to work as an advocate on these and other issues, I attempt in this book to provide balanced views on controversial issues affecting Asian Americans, such as affirmative action. Nevertheless, my conclusions no doubt reflect my personal biases and perspectives. Because of my affiliation with several organizations that have taken policy positions on key issues affecting Asian Americans and civil rights, I must stress that the positions taken in this book are my own, and do not necessarily reflect the positions of the organizations on which I serve as a member of the board of directors or with which I have been employed.

Some comments on methodology: I am a lawyer by training, and have spent my professional life as a practitioner and a teacher of law. As a lawyer, I have been schooled in doctrinal analysis, which is a unique combination of historical inquiry, linguistic interpretation, and logical argumentation. I employ this method throughout the book, although I take care to avoid the overuse of legal jargon. I draw significantly on progressive legal scholarship dealing with race, which includes a growing body of work known as Critical Race Theory. In recent years, the critical race scholars have produced an innovative literature-employing postmodernist analysis, personal histories, fiction, and other eclectic devices - in which they examine and critique racial ideology. Analyzing societal race relations and paradigms of race, I employ some of the narrative tools of Critical Race Theory, including the use of autobiographical anecdotes. I use more traditional methods in analyzing legal doctrines and recommending changes to those doctrines. I also rely on the writings of sociologists and cognitive psychologists, but I make no attempt to expound or expand on the extensive social science literature dealing with race and discrimination.

As an advocate, I am keenly aware of the limitations of legal theory, especially when advancing the interests of clients in the courts and other forums whose decision makers adhere to tradition and precedent. Many arguments presented in this book reflect a progressive critique of the law, but they also reflect a more conservative problem-solving approach that comes with working within the confines of the legal system. To the extent that my criticisms are compromised by my proposed solutions, I acknowledge that weakness here.

Finally, I extend my gratitude to the board of directors and staff of the Asian Law Caucus for their tireless work and patience, and to Melinda Gean for her assistance and support during the writing of this book. 
